\title{
EFEKTIFITAS PEMAHAMAN KONSEP IBADAH AGAMA ISLAM DENGAN MENYELENGGARAKAN KEGIATAN PESANTREN KILAT DI KELAS IV SDN 101821 PANCURBATU PADA SEMESTER 2 T.P.2018/2019
}

\author{
SYAHRIANI,S.Pd.I \\ Dinas Pendidikan Deli Serdang SD Negeri 101821 Pancurbatu
}

\begin{abstract}
The problem of this research is:1.How are the end-of-year holiday activities, especially the express curricular activities of a short-term boarding school at SDN 101821 Pancurbatu in Semester 2 T.P.2018/2019? 2. How is the correlation between extra-curricular a short-term Islamic boarding school with student learning achievement, especially in the field of Islamic studies at SDN 101821 Pancurbatu in Semester 2 T.P.2018/2019? 3. How is the relationship between the extra-curricular activities of a short-term Islamic boarding school in the end-of-year holiday and the improvement of learning achievements of grade IV students, especially in the field of Islamic studies at SDN 101821 Pancurbatu in Semester 2 T.P.2018/2019? Objectives of Action Research:1.Explaining the holiday activities of the end of the school year ;2.Explaining the improvement of learning achievement, especially in the field of Islamic studies in grade 4 students at SDN 101821 Pancurbatu in Semester 2 T.P.2018/2019.20 3. Obtaining data on the relationship between the endof-year holiday activities and the learning achievements of grade 4 students at SDN 101821 Pancurbatu in Semester 2 T.P.2018/2019.This study used three rounds of action research. Each round consists of four stages: design, activities and observations, reflections, and revisions. Data obtained in the form of formative test results, observation sheets of teaching and learning activities. From the results of analysts obtained that the conclusions that can be drawn from this PTK are: 1.Activities of grade 4 students of SDN 101821 Pancurbatu tend to increase with learning using simulation of a short-term Islamic boarding school activities 2.Cooperative skills of grade 4 students of SDN 101821 Pancurbatu during the learning process using simulation of flash a shortterm boarding school activities can appear and most showed a significant increase in Islamic learning achievements .3.Islamic learning achievements in grade 4 students at SDN 101821 Pancurbatu experienced a significant increase after learning through learning using simulations of a short-term boarding school activities It is recommended that the learning field of Islamic studies is timed to be replaced with innovative, learning techniques such as using simulated a short-term Islamic boarding school activities.
\end{abstract}

Keywords: Islamic religious worship, a short-term Islamic boarding school

\begin{abstract}
Abstrak
Masalah penelitian ini adalah :1.Bagaimana kegiatan liburan akhir tahun pelajaran terutama kegiatan ekstar kurikuler Pesantren Kilat di SDN 101821 Pancurbatu pada Semester 2 T.P.2018/2019 ? 2.Bagaimana korelasi ekstra kurikuler pesantren kilat dengan prestasi belajar siswa terutama bidang studi Agama Islam di SDN 101821 Pancurbatu pada Semester 2 T.P.2018/2019 ? 3.Bagaimana hubungan antara kegiatan ekstra kurikuler Pesantren kilat di liburan akhir tahun pelajaran dengan peningkatan prestasi belajar siswa kelas IV terutama bidang studi Agama Islam di SDN 101821 Pancurbatu pada Semester 2 T.P.2018/2019 ?Tujuan Penelitian Tindakan:1.Memaparkan tentang kegiatan liburan akhir tahun pelajaran ;2.Memaparkan tentang peningkatan prestasi belajar terutama bidang studi Agama Islam pada siswa kelas IV SDN 101821
\end{abstract}


Pancurbatu pada Semester 2 T.P.2018/2019.3.Memperoleh data tentang hubungan antara kegiatan liburan akhir tahun pelajaran dengan prestasi belajar siswa kelas IV SDN 101821 Pancurbatu pada Semester 2 T.P.2018/2019.Penelitian ini menggunakan penelitian tindakan (action research) sebanyak tiga putaran. Setiap putaran terdiri dari empat tahap yaitu: rancangan, kegiatan dan pengamatan, refleksi, dan refisi. Data yang diperoleh berupa hasil tes formatif, lembar observasi kegiatan belajar mengajar. Dari hasil analis didapatkan bahwa Kesimpulan yang dapat ditarik dari PTK ini adalah : 1.Aktivitas siswa kelas IV SDN 101821 Pancurbatu cenderung meningkat dengan pembelajaran menggunakan simulasi kegiatan pesantren kilat 2.Ketrampilan kooperatif siswa kelas IV SDN 101821 Pancurbatu selama proses pembelajaran menggunakan simulasi kegiatan pesantren kilat dapat muncul dan sebagian besar menunjukkan peningkatan prestasi belajar Agama Islam .3.Prestasi belajar Agama Islam pada siswa kelas IV SDN 101821 Pancurbatu mengalami peningkatan yang signifikan setelah dilaksanakan pembelajaran melalui Pembelajaran menggunakan simulasi kegiatan pesantren kilat Disarankan bahwa pembelajaran bidang studi Agama Islam sudah waktunya diganti dengan, teknik pembelajaran yang inovatif seperti menggunakan simulasi kegiatan pesantren kilat.

Kata Kunci: ibadah agama islam,kegiatan pesantren kilat 


\section{PENDAHULUAN}

\section{A.Latar Belakang Masalah}

Pada abad sekarang ini, peranan, tugas dan tanggung jawab guru Agama Islam semakin kompleks. Sehingga dalam tugasnya, guru Agama Islam selalu menghadapi problem-problem yang harus dipecahkan dalam rangka pencapaian tujuan pendidikan di Indonesia. Dalam hubungannya dengan pencapaian tujuan pendidikan, guru Agama Islam sebagai pelaksana operasional utama dalam proses pendidikan, selalu dituntut untuk dapat mengelola kegiatan siswa terutama di dalam kelas maupun kegiatan di luar kelas/sekolah.

Kalau tugas guru Agama Islam dalam proses pendidikan telah dilaksanakan dengan baik, serta didukung oleh komponen - komponen pendidikan lainnya dapat berfungsi sebagaimana mestinya, maka tidak ayal lagi bila tujuan pendidikan kita akan dapat terpenuhi dan tercapai dengan baik.

Melihat betapa pentingnya tugas guru Agama Islam, maka dalam rangka mencapai keberhasilan siswa dalam kegiatan belajar mengajar, guru Agama Islam dituntut juga mengelola kegiatan di luar kegiatan belajar mengajar. Hal ini sesuai dengan pendapat Raths, yang mengemukakan ada beberapa fungsi mengajar (peranan) guru Agama Islam, antara lain :

1. Initiating, managing, directing dan evaluating.

2. Memelihara kegiatan

3. Memimpin kegiatan kelompok

4. Tugas-tugas non mengajar, dan lain-lain.

Sesuai dengan fungsi/peranan yang dikemukakan oleh Raths tersebut, maka betapa pentingnya peranan guru Agama Islam dalam mengelola kegiatan non-mengajar, baik kegiatan ekstrakurikuler, maupun kegiatan-kegiatan pada hari-hari tertentu, misalnya pada hari besar nasional, liburan dan lain-lain.

Dalam liburan sekolah seringkali dilalaikan begitu saja, baik guru Agama Islam maupun para siswa untuk dimanfaatkan bagi kemajuannya. Oleh sebab itu guru Agama Islam dalam liburan-liburan sekolah terutama pada akhir tahun pelajaran yang begitu panjang itu harus mampu mengelola kegiatan tersebut sehingga mampu mengisinya dengan kegiatan yang positif baik bagi dirinya dan lebih-lebih bagi siswa. Masalah penelitian ini adalah 1. Bagaimana kegiatan liburan akhir tahun pelajaran terutama kegiatan ekstar kurikuler pesantren kilat di SDN 101821 Kecamatan Pancurbatu Kabupaten Deli Serdang pada Semester 2 T.P.2018/2019 ? 2.

Bagaimana korelasi ekstra kurikuler pesantren kilat dengan prestasi belajar siswa terutama bidang studi Agama Islam di SDN 101821 Kecamatan Pancurbatu Kabupaten Deli Serdang pada Semester 2 T.P.2018/2019? dan 3. Bagaimana hubungan antara kegiatan ekstra kurikuler pesantren kilat di liburan akhir tahun pelajaran dengan peningkatan prestasi belajar siswa kelas IV terutama bidang studi Agama Islam di SDN 101821 Kecamatan Pancurbatu Kabupaten Deli Serdang pada Semester 2 T.P.2018/2019 ? Tujuan Penelitian adalah 1.Memaparkan tentang kegiatan liburan akhir tahun pelajaran ;2. Memaparkan tentang peningkatan prestasi belajar terutama bidang studi Agama Islam pada siswa kelas IV SDN 101821 Kecamatan Pancurbatu 
Kabupaten Deli Serdang pada Semester 2 T.P.2018/2019. 3.Memperoleh data tentang hubungan antara kegiatan liburan akhir tahun pelajaran dengan prestasi belajar siswa kelas IV SDN 101821 Kecamatan Pancurbatu Kabupaten Deli Serdang pada Semester 2 T.P.2018/2019.

\section{KAJIAN PUSTAKA}

\section{A.Pengelolaan Kegiatan Liburan Akhir Tahun Pelajaran}

\section{Pengertian Pengelolaan}

Terminologi dari pengelolaan berasal dari kata "kelola" yang berarti mengurus, melakukan dan menguasai. Pengertian kelola yang semakin berkembang, terkenal dengan istilah "management".

Di dalam bahasa Indonesia, istilah "management" telah terbiasa disebut "manajemen" yang artinya sama dengan pengelolaan, dan diterjemahkan dengan kepemimpinan, ketatalaksanaan, pengusaan dan pengurusan. Ini sebenarnya kurang tepat, sebab kepemimpinan atau "leadership" hanyalah salah satu aspek daripada pengelolaan.

Sebelum menggarisbawahi pengertian pengelolaan dalam hubungan dengan tema Laporan Hasil Kegiatan Penelitian Tindakan Kelas ini, penulis berikan beberapa pendapat tentang pengertian pengelolaan atau manajemen, antara lain :

a. Menurut Dr. Ananda W.P. Guruge dalam bukunya, Prinsip-prinsip Umum Managemen Dalam Pendidikan, menyatakan bahwa :

Managemen didefinisikan sebagai suatu proses sosial yang direncanakan untuk memperoleh kerjasama, partisipasi, campur tangan serta keterlibatan orang-orang lain dalam pencapaian tujuantujuan tertentu yang telah ditetapkan secara efektif. (Ananda W.P. Guruge, $1982: 6$ )

b. Menurut Prof. Dr. Sondang P. Siagian dalam bukunya, Peranan Staf dalam Manegemen menyatakan bahwa :

Managemen adalah ketrampilan untuk memperoleh hasil dalam rangka pencapaian tujuan yang telah ditentukan sebelumnya dengan menggerakkan orang lain dalam organisasi. (Sondang P.S., $1985: 35)$

c. Menurut Dale seperti yangdi kutip oleh IKIP Surabaya dalam bukunya, Media Pendidikan dan Ilmu Pengetahuan, menyatakan bahwa :

Managemen sebagai 1. Mengelola orang-orang, 2. Pengambilan keputusan-keputusan, 3. Proses pengorganisasian dan memakai sumber-sumber untuk menyelesaikan tujuan yang telah ditentukan. (IKIP Surabaya, 1987 : 48)

Berdasarkan pendapat-pendapat tersebut di atas penulis simpulkan dalam hubungannya dengan makalah adalah : Pengelolaan (manajemen) merupakan suatu proses yang diperlukan untuk merencanakan, memimpin, mengatur, menggerakkan waktu, ruang manusia dan untuk mencapai tujuan yang telah ditetapkan sebelumnya, serta dengan manajemen diharapkan tujuan dapat tercapai secara efektif dan efisien, baik dalam proses perencanaan, pelaksanaan maupun follow-upnya..

2.Proses pengelolaan kegiatan

Berdasarkan pengertian tersebut di atas dapat diambil kesimpulan, pada dasarnya proses (aspek-aspek) dalam pengelolaan kegiatan dapat dikelompokkan menjadi tiga proses utama, yaitu : a.Merencanakan kegiatan, yaitu proses untuk menentukan tujuan-tujuan, kebijaksanaan, membuat program, menentukan metode dan prosedur serta menetapkan jadwal waktu pelaksanaan 
Seperti disampaikan dalam sebuah Kumpulan Tulisan tentang pengelolaan Dikdasmen, sebagai berikut :

Perencanaan diselenggarakan guna mengarahkan proses kegiatan kepada tujuan yang hendak dicapai. Perencanaan merupakan fungsi yang fundamental dalam pengelolaan karena perencanaan itu merupakan landasan bagi fungsi-fungsi pengelolaan lainnya. (Depdikbud, 1977 : 8)

b.Melaksanakan kegiatan, yaitu melakukan apa saja yang telah direncanakan dalam rangka mencapai tujuan yang telah ditetapkan, termasuk di dalamnya proses pengorganisasian, pengumpulan sumber-sumber, pengendalian kerja, pengawasan.

c.Follow-up (tindak lanjut) kegiatan, yaitu langkah selanjutnya yang dapat diambil sehubungan dengan telah berakhirnya kegiatan inti itu dilaksanakan, namun masih dalam lingkupnya, baik dalam rangka kesinambungan maupun peningkatan tersebut.

3.Sumber daya alam dalam pengelolaan kegiatan.

Sarana yang digunakan dalam pengelolaan suatu kegiatan untuk mencapai tujuan tidak terbatas pada manusia saja, namun juga sumber bukan manusia. Kendati demikian, manusia merupakan sumber daya utama dalam menentukan keberhasilan suatu kegiatan. Menurut Drs. M. Manullang sarana yang dipakai dalam rangka mencapai tujuan menggunakan sumber-sumber adalah sebagai berikut : "Dengan kata lain sarana (tools) atau alat manajemen untuk mencapai tujuan adalah : men, money, material, methods and markets. Kesemuanya itu disebut sumber daya". (M. Manullang, $1981:$ 17)

4.Jenis-jenis pengelolaan

Selain tugas "instructional dan educational”, guru juga mempunyai tugas mengelola atau managerial untuk mengurus dan memimpin siswanya. Tugas mengelola dalam sekolah-sekolah modern dewasa ini tidak lagi terbatas hanya dalam sekolah saja tapi juga menyangkut kegiatankegiatan di luar kelas/sekolah. Berdasarkan hal tersebut, tugas pengelolaan itu dapat digolongkan menjadi dua, yaitu :

a.Internal (di dalam sekolahan)

Tugas pengelolaan ini tidak terbatas di dalam kelasnya saja, dimana ia mengajar dan mendidik siswa-siswanya, namun kegiatan guru dalam mengelola kelasnya cukup kompleks. Yang dilakukan guru tidak hanya selama pelajaran berlangsung, akan tetapi sebelum dan sesudah pelajaran.

b. Eksternal (di luar sekolah)

Tugas pengelolaan siswa di luar sekolah ini dapat diwujudkan, antara lain :

1.Mengadakan bakti sosial di masyarakat

2.Mengelola siswa yang praktek di lapangan

3.Mengadakan kunjungan ke sekolah-sekolah lain

4.Mengadakan karya wisata

5.Mengadakan pesantren kilat.

\section{B.Liburan Sekolah Akhir Tahun Pelajaran}

Pada waktu liburan, sekolah tidak menyelenggarakan kegiatan belajar mengajar. Waktu liburan sekolah ini sebaiknya diisi dengan kegiatan yang bersifat education, yang dapat menunjang kegiatan kurikuler.

1. Jenis Liburan Sekolah 
Menurut buku Administrasi Sekolah 2 untuk SPG, liburan sekolah dapat dikelompokkan menjadi empat, yaitu :

a.Libur semester, yaitu liburan yang diadakan pada akhir setiap semester,

b.Libur umum, yaitu liburan yang diadakan untuk memperingati peristiwa nasional atau keagamaan, sesuai dengan ketentuan yang telah ditetapkan oleh Departemen Agama.

c.Libur khusus, yaitu liburan yang diadakan di luar ketentuan ketentuan libur umum,

d.Libur besar, yaitu liburan panjang yang diadakan sebagai penutup tahun pelajaran.

(Winarno Surachmad, $1979: 268$ )

2. Pengertian liburan akhir tahun pelajaran sekolah

Melihat pembagian liburan di atas, maka dapat diambil kesimpulan bahwa liburan akhir tahun pelajaran termasuk dalam jenis libur besar.

Liburan akhir tahun pelajaran sekolah adalah liburan panjang yang diadakan sebagai penutup tahun pelajaran sekolah dalam rangka kenaikan kelas/lulusan.

3.Kegiatan liburan akhir tahun pelajaran sekolah

Kegiatan yang dapat diadakan pada liburan akhir tahun pelajaran sekolah terdiri dari beberapa jenis kegiatan, diantaranya :

a.Mengadakan class meeting atau pertandingan ke luar sekolah

b.Latihan kepramukaan

c.Kegiatan-kegiatan olah raga (sepak bola, bola volley, tenis meja dan lain-lain)

d.Kegiatan kesenian (seni tari, suara, musik dan lain-lain)

e.Basar sekolah dan malam kesenian

f.Karyawisata

g.Pesantren kilat.

4.Tujuan kegiatan liburan akhir tahun pelajaran sekolah

a.Memperkaya perkembangan pribadi melalui berbagai pengalaman di luar sekolah.

b.Meningkatkan efektifitas dan efisiensi pendidikan.

c.Menyegarkan kondidi jasmani dan rohani siswa dalam menghadapi periode mengajar/belajar berikutnya.

d.Meningkatkan kesadaran siswa sebagai warga negara yang mencintai tanah air dan bangsanya.

(Winarno Surachmad, $1979: 267$ - 268)

5.Tahap-tahap pelaksanaan kegiatan liburan akhir tahun pelajaran sekolah

a.Perencanaan dan persiapan; waktu, tempat, akomodasi, peserta, transportasi dan biaya, pembagian tugas dan tanggung jawab.

b.Pelaksanaan kegiatan.

c.Tindak lanjut.

6.Alternatif kegiatan liburan akhir tahun pelajaran di SDN 101821 Kecamatan Pancurbatu Kabupaten Deli Serdang pada Semester 2 T.P.2018/2019.

a. Karyawisata

Conny Semiawan dalam bukunya Pendekatan Ketrampilan Proses, menyatakan bahwa : "Metode karyawisata adalah suatu cara menyajikan bahan pelajaran dengan membawa siswa langsung kepada obyek yang akan dipelajari yang terdapat di luar kelas". (Conny Semiawan, 1984 : 79) 
Disini, karyawisata selain dapat digunakan sebagai metode mengajar dalam rangka kegiatan belajar mengajar, dapat juga dipakai sebagai kegiatan untuk mengisi hari-hari tertentu.

Dalam kenyataannya belajar siswa itu tidak terbatas hanya di kelas/sekolah, atau di rumah saja, melainkan sewaktu-waktu perlu pergi ke suatu tempat lain untuk mempelajari sesuatu hal tertentu. Biasanya karya wisata dilakukan dalam rangka mempelajari sesuatu bagian mata pelajaran, namun sebenarnya karya wisata dapat digunakan untuk bermacam-macam pelajaran. Satu obyek wisata dapat dijadikan tujuan yang berbeda-beda dari bermacam-macam mata pelajaran.

Tujuan atau fungsi karyawisata, antara lain sebagai kegiatan rekreasi sambil mempelajari sesuatu bahan mata pelajaran, karya wisata juga dapat sebagai salah satu teknik dalam bimbingan kelompok.

Tempat yang dapat dijadikan obyek karya wisata antara lain ; museum, taman hewan, industri, pegunungan, peninggalan sejarah (candi, keraton dan lain-lain). Keuntungan mengadakan kegiatan karya wisata :

1.Siswa dapat mengamati obyek secara langsung, dengan jalan siswa melihat, mendengarkan, wawancara, membuktikan.

2.Siswa dapat mengganti, pengalaman-pengalaman dengan mencoba turut serta dalam suatu kegiatan.

3.Siswa dapat mempelajari bermacam-macam mata pelajaran secara integral dalam suatu kegiatan.

4.Siswa dapat mengembangkan, menanamkan serta memupuk rasa cinta terhadap alam sekitar dan tanah air.

Kelemahan mengadakan kegiatan karya wisata :

1.Kadang-kadang terdapat kesulitan dalam hal biaya, waktu, tenaga dan transportasi.

2.Jarang dapat dilaksanakan karena dapat mengganggu pelajaran.

b.Ekstrakurikuler

Kegiatan ekstrakurikuler bertujuan agar siswa dapat lebih memperkaya dan memperluas pengetahuan, mendorong pembinaan nilai/sikap, serta memungkinkan penerapan lebih lanjut pengetahuan yang telah dipelajari dari berbagai mata pelajaran dalam kurikulum, baik program inti maupun program khusus. Perlu diperhatikan bahwa kegiatan ekstrakurikuler ini mengutamakan kegiatan kelompok.

Jenis kegiatan ekstrakurikuler yang dapat di pilih untuk dilaksanakan, antara lain :

1.Pramuka,

2.P M R,

3.Olah raga

4.Kesenian

5.dan lain sebagainya.

Azas-azas yang perlu diperhatikan dalam pelaksanaan kegiatan ekstrakurikuler sekolah :

1.Persiapan yang mantap dalam hal program pelaksanaan dan kemudian pembiayaan,

2.Koordinasi antara kepala sekolah, wali kelas, guru maupun pihak-pihak yang berkepentingan,

3.Pelaksanaan dilakukan di luar jam pelajaran tatap muka, termasuk pada hari libur,

4.Pelaksanaan diikuti seluruh siswa atau sebagian siswa menurut jenis dan fungsinya. (Depdikbud,। $1984: 23$ )

Kebaikan kegiatan ekstrakurikuler : 
1.Mampu mengembangkan bakat siswa, dengan jalan menyalurkan bakat dan minat yang ada pada siswa untuk salah satu kegiatan yang diadakan oleh sekolah.

2.Dapat memberikan pengetahuan dan ketrampilan praktis pada siswa.

3.Dapat menunjang program mata pelajaran sekolah apabila kegiatan itu dilakukan secara kontinyu dan ada petugas yang mempunyai keahlian tertentu pada bidangnya.

Kelemahan kegiatan ekstrakurikuler :

1.Biasanya terbentur masalah biaya, tenaga dan waktu.

2.Kalau jumlah siswa terlalu banyak mengikuti kegiatan, sulit mengkoordinirnya karena terbatasnya tenaga.

3.Kalau siswa terlalu banyak mengikuti jenis kegiatan, dapat mengganggu konsentrasi belajarnya.

4.Pelaksanaan harus kontinyu untuk mendapatkan hasil yang memuaskan.

c.Pesantren kilat

Seperti disampaikan oleh Bapak Presiden Soeharto, dikutip oleh Media Pembinaan Pendidikan sebagai berikut :

Agar memanfaatkan waktu libur dengan kegiatan yang berpahala, melalui Pesantren Kilat. Melalui Pesantren Kilat, kita ingin agar anak-anak kita makin memahami, lebih menghayati dan makin banyak mengamalkan ajaran Islam yang mereka anut. (Media PP, 1997 : 3)

Siswa yang merupakan sumber daya insani yang potensial bagi pembangunan bangsa, oleh karena itu perlu terus dibina dan dikembangkan sesuai dengan tujuan pendidikan nasional, yaitu mencerdaskan kehidupan bangsa dan mengembangkan manusia Indonesia seutuhnya, yaitu manusia Indonesia yang beriman dan bertaqwa kepada Tuhan Yang Maha Esa dan berbudi pekerti luhur, memiliki pengetahuan dan ketrampilan, kesehatan jasmani dan rohani, kepribadian yang mantap dan mandiri serta rasa tanggung jawab kemasyarakatan dan kebangsaan.

Untuk mewujudkan tujuan pendidikan nasional tersebut, khususnya dalam hal keimanan dan ketaqwaan terhadap Tuhan Yang Maha Esa serta budi pekerti luhur, di sekolah diupayakan pencapaian melalui mata pelajaran Pendidikan Agama yang wajib diikuti oleh seluruh peserta didik pada semua jenjang pendidikan. Kendati demikian pelajaran Pendidikan Agama di sekolah masih kurang, terutama jumlah jamnya yang sangat terbatas. Sehingga tujuan Pendidikan Agama di sekolah sulit dicapai. Untuk melengkapi kekurangan tersebut perlu diciptakan kegiatan sekolah yang mengarah pada peningkatan keimanan dan ketaqwaan serta budi pekerti. Kegiatan dimaksud antara lain adalah melalui Pesantren Kilat, yang dewasa ini semakin banyak diselenggarakan oleh sekolah dan lembaga lain dalam masyarakat dengan memanfaatkan waktu libur sekolah.

1.Metode

Beberapa alternatif metode yang dapat digunakan dalam proses kegiatan pesantren kilat antara lain :

a.Ceramah, yaitu suatu cara mengajar atau penyajian materi melalui penuturan dan penerapan lisan oleh guru kepada siswa.

b.Tanya jawab, yaitu metode yang dikembangkan untuk terjadinya komunikasi timbal balik antara siswa dengan pembimbing dan memperluas cakrawala berpikir atau berbagai persoalan.

c.Metode diskusi, yaitu suatu cara penyampaian materi melalui pengajuan suatu topik kemudian dibahas bersama-sama.

d.Cerita, yaitu metode yang dianggap efektif untuk pewarisan nilai kebenaran dan keteladanan tokoh - tokoh Islam dan perjuangannya kepada para peserta. 
e.Sosiodrama (bermain peran), yaitu siswa dapat dilatih melakukan suatu aktifitas sosial melalui metode sosiodrama.

f.Demonstrasi, yaitu siswa diminta melakukan suatu kegiatan peragaan / praktek, seperti, tata cara berwudlu, shalat, memakai mukena, memakai kerudung/busana muslim, manasik haji dan lain sebagainya.

g.Metode latihan (drill), yaitu suatu cara penyajian materi atau kegiatan yang dilakukan dengan cara berulang-ulang dan bersungguh-sungguh dengan tujuan untuk memperkuat dan menyempurnakan suatu kegiatan atau ketrampilan.

h.Kunjungan lapangan/karyawisata, yaitu kegiatan pendidikan yang realistis dan berguna untuk memperoleh pengalaman langsung masalah-masalah yang ada di lingkungan sekitar.

i.Pemberian tugas, yaitu penugasan kepada siswa untuk menambah ketrampilan dan kemampuan praktis atas berbagai persoalan yang berkaitan dengan nilai agama.

2. Materi

Ruang lingkup materi pesantren kilat di sekolah dasar mencakup segala usaha mewujudkan keserasian, keselarasan dan keseimbangan antara lain :

a.Hubungan manusia dengan Allah (habluminallah)

b.Hubungan manusia dengan sesama manusia (habluminanas)

c.Hubungan manusia dengan dirinya sendiri

d.hubungan manusia dengan makhluk Allah lainnya dan lingkungan alam sekitarnya (habluminal ghairiyah).

Materi pesantren kilat di Sekolah Dasar meliputi tujuh unsur pokok, yaitu :

a.Keimanan, diantaranya :

1.Meyakini rukun iman

2.Meyakini sifat Allah Yang Maha Esa

3.Meyakini sifat Allah Yang Maha Dekat

4.Penghayatan sifat Allah Maha Pengasih, Maha Penyayang, Maha Pemurah.

5.Meyakini tentang kitab Al-Qur'an

6.Penghayatan teladan Nabi Musa a.s.

7.Penghayatan teladan Nabi Isa a.s.

b.Ibadah, diantaranya :

1.Pengenalan rukun Islam

2.Bimbingan praktek bersuci

3.Bimbingan berwudhu

4.Bimbingan adzan

5.Bimbingan iqamah

6.Bimbingan bacaan shalat

7.Bimbingan praktek shalat

8.Bimbingan doa wiridz setelah shalat

9.Bimbingan shalat berjamaah.

c. Al Qur'an, diantaranya :

1.Praktek melafalkan dan menghafalkan surat-surat pendek Al Qur'an.

2.Membaca huruf-huruf hijaiyah tunggal

3.Membaca huruf sambung 


\section{Membaca lancar}

d.Akhlak, diantaranya :

1.Cara berakhlak mulia kepada Allah

2.Bimbingan akhlak kepada orang tua

3.Bimbingan akhlak kepada kakak dan adik

4.Bimbingan akhlak kepada teman

5.Bimbingan akhlak kepada guru

6.Bimbingan akhlak kepada tetangga

7.Bimbingan cara bersilaturahmi

8.Dan lain-lain

e.Muamalah, diantaranya :

1.Pengenalan hukum pinjam-meminjam

2.Pengenalan sikap jujur

3.Pengenalan terhadap sikap amanah dan dapat dipercaya

4.Membiasakan diri berbuat benar

f.Tarikh, diantaranya :

1.Kisah Nabi Muhammad SAW.

2.Kisah para sahabat Nabi Muhammad SAW.

g.Tambahan, diantaranya :

1.Melakukan olahraga secara benar dan sopan

2.Melakukan kegiatan kesenian Islami

3.Pemecahan masalah

4.Kegiatan bakti sosial

3. Waktu dan tempat

a.Waktu

Hari dan tanggal pelaksanaan disesuaikan dengan masa awal liburan besar (liburan akhir tahun). Sehingga pesantren kilat merupakan program pengisi waktu luang pada musim liburan. Sedang lama pelaksanaan di tingkat Sekolah Dasar adalah 7 hari ( 7 x 24 jam ).

b.Tempat pelaksanaan pesantren kilat di SDN 101821 Kecamatan Pancurbatu Kabupaten Deli

Serdang pada Semester 2 T.P.2018/2019. .

4.Organisasi penyelenggaraan

a.penanggung jawab penyelenggara

b.penanggung jawab program

c.fasilitator

d.Pembina kegiatan

e.Panitia pelaksana

: Kepala Sekolah

: Guru Pendidkan Agama Islam

: Penilik / Pengawas pendala

: Tokoh masyarakat/ulama, guru yang beragama Islam yang ditunjuk.

: Dibentuk sesuai dengan kebutuhan sekolah, dengan melibatkan sekolah yang tergabung dan Komite Sekolah.

5. Ketenangaan

a. Pengawas

b. Kepala Sekolah

c. Guru Pendidikan Agama Islam 
d. Guru yang beragama Islam

e. KOMITE SEKOLAH / orang tua siswa

f.Tokoh masyarakat

6.Pembiayaan

Biaya kegiatan pesantren kilat ini ditanggung bersama antara sekolah dengan orang tua siswa. Sumber dana lain yang diusahakan melalui sumbangan yang syah, halal, dan tidak mengikat.

7.Sarana dan prasarana

Sarana dan prasarana yang digunakan untuk kegiatan pesantren kilat pada dasarnya sarana dan prasarana yang ada di sekolah penyelenggara.

8. Evaluasi

Yaitu evaluasi yang bertujuan untuk mengetahui sejauh mana keberhasilan siswa dalam mengikuti pesantren kilat, baik mengenai pengetahuan, sikap dan ketrampilan.

a. prosedur evaluasi, pretest (tes awal), post test (tes akhir)

b. Alat evaluasi :

- tes : tes tertulis, tes lisan, tes perbuatan

- non tes : pengamatan, laporan.

c. Aspek yang dievaluasi : pengetahuan, sikap kepribadian, ketrampilan. 


\section{A. Klasifikasi Tindakan}

Dalam penyelenggraan Penelitian Tindakan kelas oleh penulis, maka berfokus masalah adalah peningkatan hasil belajar Agama Islam bagi siswa SDN 101821 Kecamatan Pancurbatu Kabupaten Deli Serdang pada Semester 2 T.P.2018/2019 melalui pendekatan pembelajaran dengan menggunakan kegiatan ektra kurikuler pesantren kilat

Jenis penelitian yang akan digunakan tergolong pada penelitian kelas (classroom reaserch) dengan bentuk khusus penelitian tindakan yang dilakukan di kelas yang lazim disebut penelitian tindakan kelas (classroom actian research).

Penelitian tindakan kelas mampu menawarkan pendekatan dan prosedur baru yang lebih menjanjikan dampak langsung dalam bentuk perbaikan dan peningkatan profesionalisme guru dalam mengelola proses belajar di kelas atau implementasi berbagai program di sekolah dengan mengkaji berbagai indikator keberhasilan proses dan hasil pembelajaran yang terjadi pada siswa. Hal tersebut sesuai dengan yang dikemukakan oleh Stenhause di Hopkin 1993 dalam kasbollah bahwa :

"Penelitian Tindakan Kelas membuat guru dapat meneliti dan mengkaji pembelajaran yang ia lakukan di kelas sehingga permasalahan yang dihadapi adalah permasalahan aktual. Dengan demikian guru dapat langsung berbuat sesuatu untuk memperbaiki praktik-praktik pengajaran yang kurang berhasil agar menjadi lebih baik dan lebih efektif. Dalam hal ini guru dilatih untuk dapat mengendalikan kehidupan profesinya serta terlibat dalam pengambilan keputusan secara profesional."

Selain itu Ebbuf (1285) dalam Kasbollah mengemukakan bahwa :

"Penelitian tindakan kelas merupakan studi yang sistimatis yang dilakukan dalam upaya memperbaiki praktik-praktik dalam pendidikan dengan melakukan tindakan-tindakan praktis serta refleksi dari tindakan tersebut yang berupa suatu rangkaian siklus yang berkelanjutan dan diantara siklus-siklus itu ada informasi yang merupakan balikan."

Bentuk penelitian kelas yang penulis gunakan adalah penelitian tindakan kelas yang bersifat kolaboratif dan partisipatoris. Sesuai dengan yang diungkapkan Kasbolah (1999: 14), bahwa sebagai dasar pemikiran, Lewin (orang yang mempopulerkan penelitian tindakan) menekankan pentingnya kolaboratif dan partisipatoris. Kolaboratif diterapkan untuk menciptakan adanya hubungan kesejawatan kerja sedangkan partisipatoris merupakan penelitian tindakan kelas yang pada pelaksanaannya melibatkan guru kelas.

Penulis memilih metode mi dengan pertimbangan bahwa guru kelas merupakan pihak yang langsung mengalami dan menemukan berbagai masalah pembelajaran.

Dengan penelitian tindakan kelas diharapkan dapat meningkatkan kinerja dan kemampuan guru dalam rangka meningkatkan mutu pembelajaran serta terciptanya hubungan antar guru Agama Islam dalam mencari jalan pemecahan permasalahan yang terjadi dalam pembelajaran.

\section{B. Tempat dan Responden Penelitian Tindakan}

Peneliti menunjuk SDN 101821 Kecamatan Pancurbatu Kabupaten Deli Serdang sebagai tempat kegiatan penelitian ilmiah disebabkan karena sekolah tersebut tempat peneliti sebagai guru Agama Islam.Selain itu letaknya sangat strategis, mudah dijangkau oleh masyarakat di sekitarnya dan berada di daerah pertanian yang tidak jauh dari kawasan kota. Minat masyarakat untuk menyekolahkan anaknya di SDN 101821 Kecamatan Pancurbatu Kabupaten Deli Serdang sangat 
tinggi di mana setiap penerimaan siswa baru yang mendaftar sangat banyak. Sebagian besar siswa yang belajar di sekolah ini berasal dari daerah sekitar sekolah. Walaupun jarak terjauh sekitar $3 \mathrm{~km}$ namun tidak menjadi hambatan karena siswa yang jauh dapat dengan mudah pergi ke sekolah naik kendaraan umum. Latar belakang ekonomi dari orang tua siswa termasuk cukup, Sebagian besar orang tua siswa berdagang di kawasan kota dan bertani sayuran.

\section{Langkah-langkah Tindakan}

Dalam proses penelitian tindakan kelas di buat beberapa siklus sebagai langkah awal untuk mengadakan tindakan. Setelah satu siklus selesai diadakan refleksi untuk melakukan tindakan selanjutnya. Adapun alur pelaksanaan tindakan yang digunakan adalah model Kemmis dan Mc.Targart. Alur pelaksanaan tindakan dapat dilihat pada gambar berikut:

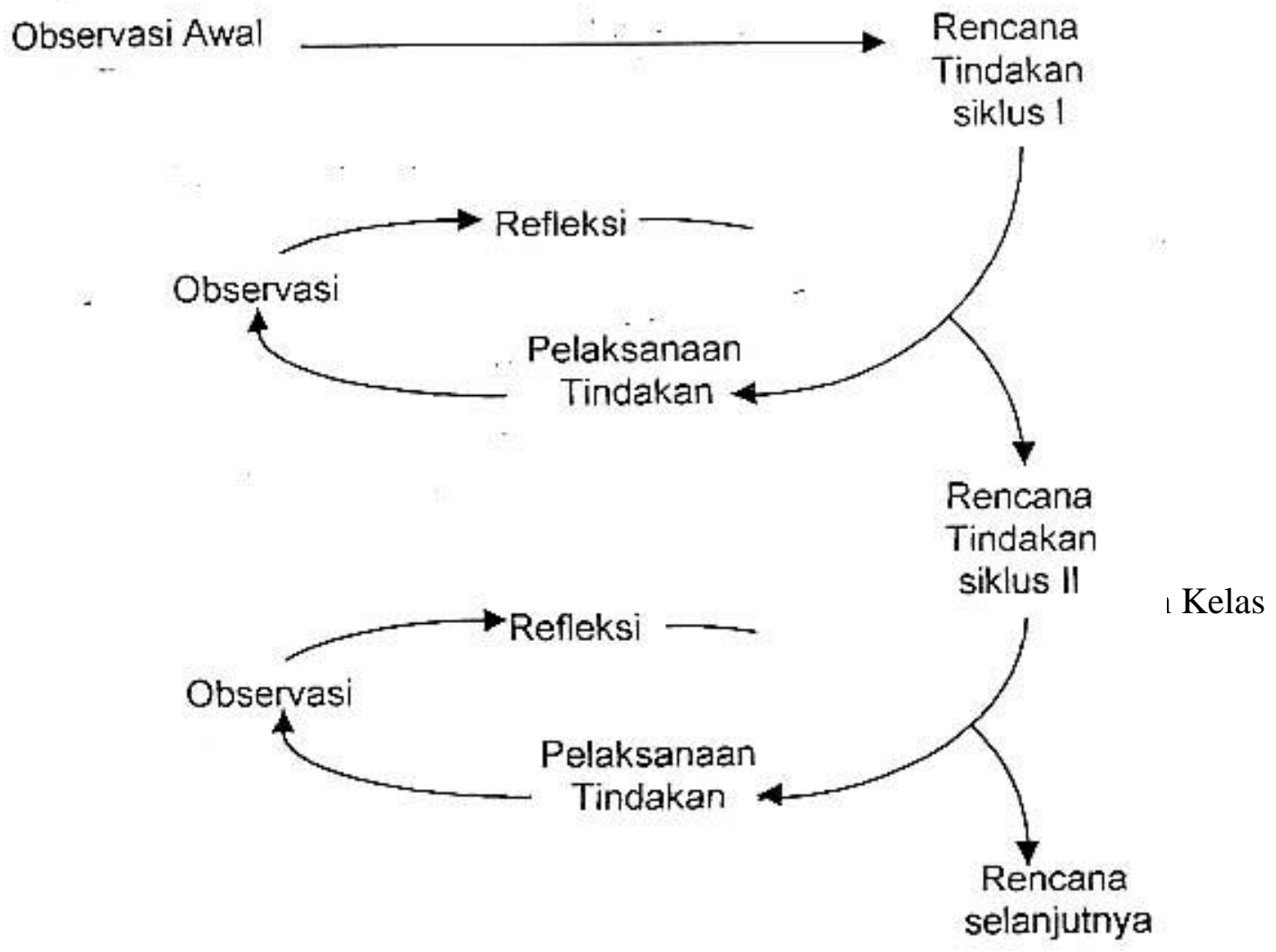


Secara rinci prosedur penelitian tindakan kelas SDN 101821 Kecamatan Pancurbatu Kabupaten Deli Serdang pada Semester 2 T.P.2018/2019 dapat dikabarkan sebagai berikut:

\section{Analisis Kurikulum 13}

Analisis kurikulum dilakukan peneliti untuk mempelajari kompetensi dasar dari mata pelajaran Agama Islam di kelas IV, kemudian peneliti menetapkan tema yang akan digunakan yakni pendekatan pembelajaran dengan menggunakan kegiatan ektra kurikuler Pesantren Kilat 2.Observasi Awal.

Melakukan observasi di kelas IV SDN 101821 Kecamatan Pancurbatu Kabupaten Deli Serdang pada Semester 2 T.P.2018/2019 sebagai subyek penelitian terutama difokuskan pada pembelajaran yang dilakukan selama ini. Masalah yang ditemukan dari observasi awal oleh peneliti akan dijadikan sebagai acuan dalam perencanaan tindakan.

3.Perencanaan Tindakan

a. Membuat silabus tentang pembelajaran dan skenario pembelajarannya.

b. Membuat lembar kerja siswa untuk mengukur kemampuan siswa dalam tema yang dipilih dalam pendekatan pembelajaran dengan menggunakan kegiatan ektra kurikuler Pesantren Kilat .

c. Membuat lembar evaluasi untuk mengukur kemampuan siswa sebelum dan setelah dilaksanakannya pembelajaran dengan menggunakan kegiatan ektra kurikuler Pesantren Kilat

d. Membuat lembar observasi untuk mengamati sikap dan aktivitas siswa selama terjadi pembelajaran dengan menggunakan kegiatan ektra kurikuler Pesantren Kilat .

4.Pelaksanaan Tindakan

a. Guru dan siswa menyiapkan alat-alat pelajaran yang diperlukan selama pembelajaran berlangsung.

b. Pembagian kelompok belajar agar siswa dapat bekerja sama dan berdiskusi untuk melakukan kegiatan dan menjawab soal yang ada dalam LKS.

c. Guru mengadakan apersepsi melalui tanya jawab yang ada kaitannya dengan tema yang akan di gunakan dalam pendekatan pembelajaran dengan menggunakan kegiatan ektra kurikuler pesantren kilat .

d. Guru mengadakan tes awal untuk mengetahui pengetahuan awal siswa sebelum dilaksanakan dalam pembelajaran memalui pendekatan pembelajaran dengan menggunakan kegiatan ektra kurikuler Pesantren Kilat .

e. Penyampaian materi dengan pembelajaran terpadu.

f. Setiap kelompok mengerjakan LKS.

g. Guru melakukan observasi selama pembelajaran berlangsung dan membuat catatan lapangan.

h. Setiap kelompok melaporkan hasil kegiatan dalam diskusi kelas.

i. Kelompok lain memberi tanggapan kritik ataupun saran.

j. Siswa dengan bimbingan guru merumuskan kesimpulan hasil diskusi.

k. Siswa mengerjakan soal-soal dalam lembai evaluasi sebagai akhir pembelajaran untuk mengukur kemampuan siswa setelah pembelajaran terpadu dilaksanakan.

1. Guru memberi penilaian sebagai hasil belajar siswa.

1. Observasi

Proses observasi dilakukan selama pembelajaran berlangsung dengan lembar observasi yang telah dibuat dalam setiap tindakan. 


\section{Refleksi}

Peneliti mengkaji hasil dari observasi selama pembelajaran terpadu berlangsung, lembar kerja siswa, dan tes. Setiap kekurangan dan kesalahan yang ditemukan selama pembelajaran melalui pendekatan kebiasaan menonton televisi dapat dipakai sebagai acuan dalam merencanakan tindakan dalam siklus berikutnya.

\section{Teknik / Metode Penelitian}

Selama penelitian, peneliti menggunakan beberapa instrumen penelitian yaitu:

Tes

Tes digunakan untuk memperoleh data mengenai kemampuan siswa sebelum dan sesudah dilakukan tindakan. Soal pretes dan postes sama. Untuk menghindari bias dari hasil kedua tes maka dilakukan: a)Soal pretes ditarik kembali b) setelah pretes tidak dilakukan pembahasan soal c) penggunaan soal yang sama tidak diberitahukan.

Lembar Kerja Siswa

Untuk memperoleh data mengenai pengetahuan, pemahaman, dan keterampilan siswa setelah pembelajaran melalui pendekatan pembelajaran dengan menggunakan kegiatan ektra kurikuler Pesantren Kilat .

Lembar Observasi

Untuk memperoleh data ilmiah yang dimiliki siswa yang berkembang selama proses pembelajaran melalui pendekatan pembelajaran dengan menggunakan kegiatan ektra kurikuler Pesantren Kilat sehingga dapat diperoleh data aktivitas siswa setiap tindakan. 


\section{HASIL PENELITIAN TINDAKAN DAN PEMBAHASAN}

\section{A. Persiapan Tindakan}

Penelitian Tindakan Kelas yang mengambil setting di SDN 101821 Kecamatan Pancurbatu Kabupaten Deli Serdang pada Semester 2 T.P.2018/2019, pelaksanaannya mengikuti alur sebagai berikut :

1. Perencanaan, meliputi penetapan materi pembelajaran agama Islam dan penetapan alokasi waktu pelaksanaannya.).

2. Tindakan, meliputi pada proses kegiatan belajar mengajar bidang studi agama Islam melalui kegiatan dengan menggunakan menyelenggarakan pesanten kilat.

3. Observasi, dilaksanakan bersamaan dengan proses pembelajaran, meliputi aktivitas siswa, pengembangan materi, dan hasil belajar siswa.

4. Refleksi, meliputi kegiatan analisis hasil pembelajaran dan sekaligus menyusun rencana perbaikan pada siklus berikutnya.

Pelaksanaan penelitian dilakukan secara kooperatif dengan guru kelas, yang membantu dalam pelaksanaan observasi dan refleksi selama penelitian berlangsung, sehingga secara tidak langsung kegiatan penelitian bisa terawasi sekaligus menjaga kevalidan hasil penelitian.

\section{B. Hasil Penelitian Tindakan}

Penelitian Tindakan Kelas dengan alur atau tahapan (perencanaan, tindakan, obeservasi, refleksi) pada siswa kelas IV SDN 101821 Kecamatan Pancurbatu Kabupaten Deli Serdang pada Semester 2 T.P.2018/2019 sebagai berikut

\section{Tahap Perencanaan}

Pada tahap ini menyusun satuan pelajaran, kemudian menyiapkan alat peraga.

\section{Tahap Tindakan.}

Pada tahap ini siswa disuruh membuat 4 kelompok yang terdiri masing-masing kelompok 3-4 anak. Kemudian masing-masing kelompok guru memberikan pola permainan seperti contoh soal berikut :

a. Salah satu siswa disuruh membuat aktivitas religius meliputi ( mengaji, sholat dan bermain ) sementara siswa yang lain mengikuti atau membuat kegiatan tandingan yang sama dengan kelompok lainnya.

b. Dari pelbagai kegiatan yang sudah diarahkan terlebih dahuku oleh guru Agama Islam, maka siswa diberi tugas mengisi agenda kegiatan seolah-oleh terjadi pesantren kilat di bulan ramadhan.

c. Siswa disuruh melakukan secara berkelompok namun terpisah antara kelompok satu dengan kelompok lainnya.

3. Tahap Observasi.

Pada tahap ini guru Agama Islam mengamati kecakapan siswa dalam aktivitas keagamaam yang mencitrakan rutinitas sehari-hari di rumah dan memantau kerjasama antar siswa dalam memecahkan pelbagai permasalahan seputar do'a dan gerakan wudhu dan sholat yang syah dan benar.

4. Tahap refleksi. 
Pada tahap ini guru Agama Islam mencatat hasil prestasi kerja praktek siswa dan mengamati tiap-tiap kelompok dalam menjawab permasalahan dan ketepatan jadwal kegiatan yang sudah ditentukan oleh guru Agama Islam sebelumnya. Kemudian mengevaluasi hasil keseluruhan pembelajaran tersebut dan memperbaiki kelemahan yang ada untuk pembelajaran berikutnya.

Dari keempat tahapan tersebut kemudian diulangi lagi mulai dari tahap perencanaan sampai tahap refleksi secara simultan yang pada akhirnya diperoleh suatu peningkatan prestasi belajar pada pembelajaran Agama Islam dengan menggunakan kegiatan pesantren kilat.

\section{Konfirmasi refleksi}

Proses analisis data sebagai hasil penelitian meliputi peningkatan aktivitas dan pemunculan ketrampilan siswa dalam menggunakan kegiatan pesantren kilat, serta memantau secara regular hasil prestasi belajar siswa kelas IV SDN 101821 Kecamatan Pancurbatu Kabupaten Deli Serdang pada Semester 2 T.P.2018/2019 dalam memahami materi pelajaran agama Islam secara konkrit .

Dalam proses pembelajaran Agama Islam pengenalan materi sholat, wudhu, mengaji dan bermain dilakukan dengan diskusi dalam asing-masing kelompok guna memecahkan kendalakendala yang ditemui siswa, kemudian dilanjutkan dengan pemberian tugas LKS. Hasil penelitian menunjukkan :

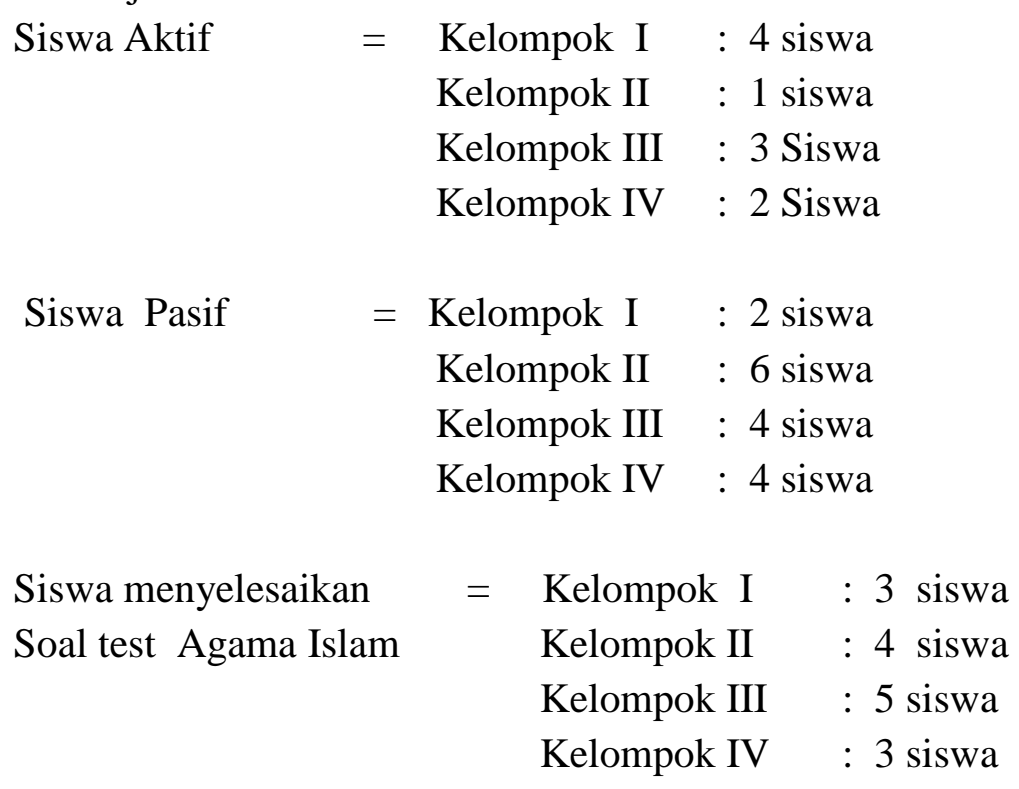

\section{$\underline{\text { Interpretasi }}$}

Pengenalan materi Agama Islam cukup jelas bagi siswa dan cukup dimengerti, namun ketepatan dan kebersamaan dalam sholat berjamaah siswa kelas IV SDN 101821 Kecamatan Pancurbatu Kabupaten Deli Serdang pada Semester 2 T.P.2018/2019 masih terasa gugup sehingga perlu pendampingan pembelajaran secara kontinyu.

\section{Pembahasan Atas Hasil Tindakan}

Hasil penelitian menunjukkan bahwa kemampuan siswa dalam memahami materi Agama Islam dengan menggunakan kegiatan simulasi pesantren kegiatan pesantren kilat adalah cukup 
memuaskan. Secara keseluruhan hasil penelitian menunjukkan adanya peningkatan, baik aktivitas, kerjasama, maupun prestasi siswa, seperti pada tabel berikut : 
Tabel I

Hasil Penelitian

\begin{tabular}{|l|c|c|c|c|}
\hline \multicolumn{1}{|c|}{ Nama } & $\begin{array}{c}\text { Jumlah Siswa } \\
\text { Aktif }\end{array}$ & $\begin{array}{c}\text { Jumlah Siswa } \\
\text { Pasif }\end{array}$ & $\begin{array}{c}\text { Jumlah siswa yang benar } \\
\text { menjawab }\end{array}$ & Persentase \\
\hline Kelompok I & 4 & 2 & 4 & $80 \%$ \\
\hline Kelompok II & 4 & 3 & 5 & $90 \%$ \\
\hline Kelompok III & 3 & 3 & 6 & $100 \%$ \\
\hline Kelompok III & 3 & 3 & 4 & $80 \%$ \\
\hline
\end{tabular}

Salah satu hasil observasi selain tiga hal yang menjadi sasaran tindakan penelitian adalah dengan berkembangnya pemahaman materi Agama Islam sejalan dengan berkembangnya aktivitas dan ketrampilan kooperatif siswa selama kegiatan simulasi pesantren kilat. Dengan kata lain, semakin siswa memahami materi Agama Islam (tata cara sholat yang sah dan benar, tata cara pengambilan air wudhu yang benar dan dapat menghilangkan najis dan hadats kecil, juga perlahanlahan siswa mengerti belajar bahasa arab dengan mengaji secara rutin) semakin eksis dan mantap serta antusias dalam beraktivitas terutama dalam kelompoknya masing-masing. 
Tabel 2

\section{Grafik Hasil Penelitian}

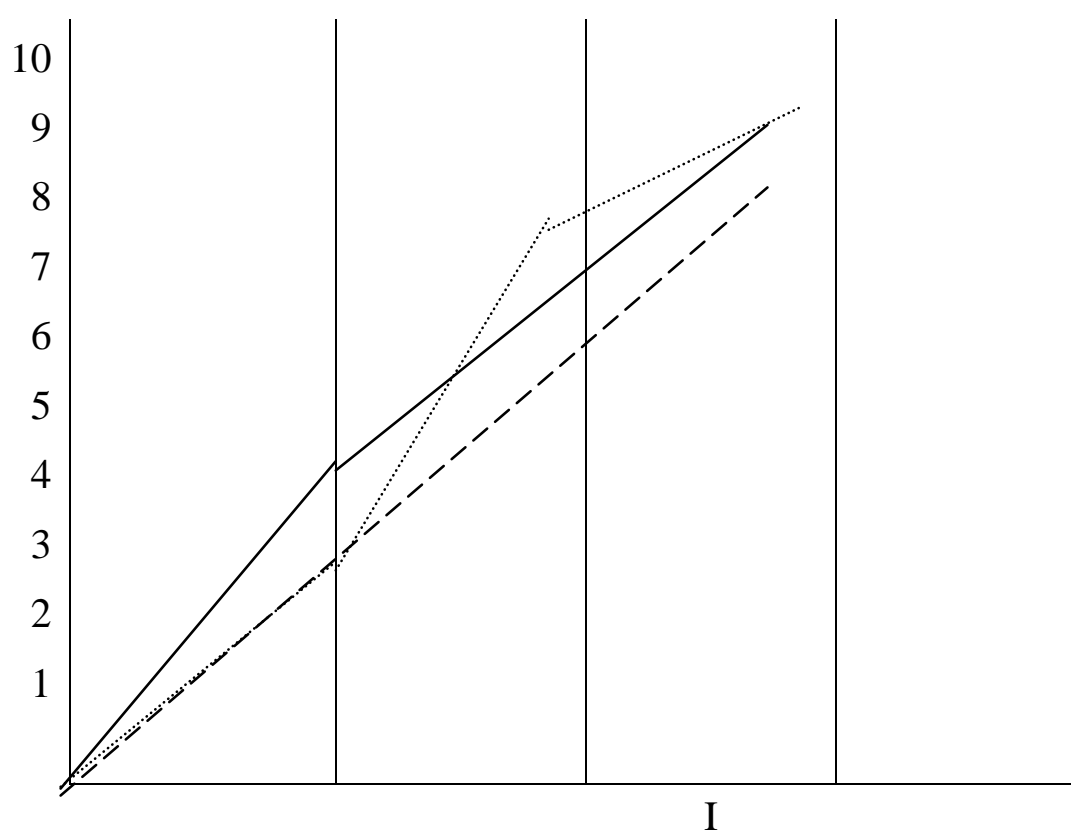

Hasil Prestasi belajar

Siswa Aktif

Siswa Pasif 


\section{KESIMPULAN DAN SARAN}

\section{A. Kesimpulan}

Kesimpulan yang dapat ditarik dari PTK ini adalah :

1. Aktivitas siswa kelas IV SDN 101821 Kecamatan Pancurbatu Kabupaten Deli Serdang pada Semester 2 T.P.2018/2019 cenderung meningkat dengan pembelajaran menggunakan simulasi kegiatan pesantren kilat.

2. Ketrampilan kooperatif siswa kelas IV SDN 101821 Kecamatan Pancurbatu Kabupaten Deli Serdang pada Semester 2 T.P.2018/2019 selama proses pembelajaran menggunakan simulasi kegiatan pesantren kilat dapat muncul dan sebagian besar menunjukkan peningkatan prestasi belajar Agama Islam .

3. Prestasi belajar Agama Islam pada siswa kelas IV SDN 101821 Kecamatan Pancurbatu Kabupaten Deli Serdang pada Semester 2 T.P.2018/2019 mengalami peningkatan yang signifikan setelah dilaksanakan pembelajaran melalui simulasi kegiatan pesantren kilat

\section{B. Saran-saran}

Dari kesimpulan di atas, dapat penulis menyarankan bahwa pembelajaran yang efektif dan inovatif bagi materi pelajaran khususnya bidang studi Agama Islam yang selama ini hanya menggunakan cara-cara konvensional sudah waktunya diganti dengan, teknik pembelajaran yang inovatif seperti menggunakan simulasi kegiatan pesantren kilat.

Penggunaan media pembelajaran sangat dipentingkan untuk instrument pengajaran saat ini terutama yang berkaitan dengan ilmu pengetahuan lain seperti PPKn, SBK dan lainnya, guru Agama Islam harus lebih kompetentif terhadap perkembangan informasi pembelajaran guna pemenuhan target kegiatan belajar mengajar di kelas, dengan demikian mutu mengajar dan antusiasme siswa lebih konsentarsi terhadap kegiatan proses pembelajaran di sekolah. 


\section{DAFTAR PUSTAKA}

Bahan Penataran, Sistem Pembinaan Profesional Guru SD / MI tahun 2006. Proyek Peningkatan Pembinaan Pendidikan Dasar (P4D), Jawa Timur.

Depdikbud, 1994, Kurikulum Pendidikan Dasar GBPP Kelas VI, Jakarta ; Depdikbud.

Depdiknas, 2003, Undang-Undang RI Nomor 20, Sisdiknas ; Jakarta ; Depdiknas.

Dryden, Gordon, 2001, The Learning Revolution, Bandung : Kaifa.

Kasbolah, Kasihani, ES, 2001, Penelitian Tindakan Kelas, Malang ; UM.

Khoiriyah, 2004, Pesantren Kilat Sebagai Media Wahana Pembelajaran Agama Islam secara efektif dan Aplikatif, Bandung : Media Nusantara 